\title{
INVESTING IN THE FINANCIAL SECTOR OF EMERGING COUNTRIES: POTENTIAL RISKS AND HOW TO MANAGE THEM'
}

\author{
Sonsoles Gallego, Alicia García Herrero and Cristina Luna² \\ Banco de España
}

\begin{abstract}
The purpose of this article is to assess how the changing operations of international banks in emerging countries in the last decades have altered the risks they face as well as their mitigation techniques. The recent expansion of the international banking business through the setup of branches and subsidiaries has increased business potential, but has also changed the nature of the risks faced. Nevertheless, it is hard to determine whether risks, on the whole, are larger now than when cross-border operations were the main instrument for international banks' activity. In addition, the article describes the various channels through which the risks faced by banks operating in emerging countries increase in times of crisis, especially when operating locally and in highly dollarized host countries, as shown in the latest crisis events. While the financial independence of subsidiaries may be considered an important tool of risk control, the possibilities to mitigate risks in local markets during times of crisis are generally scarce. This could be due to the relatively recent expansion of foreign banks' local operations in emerging countries, as compared to the cross-border business, together with the relative underdevelopment of local financial markets, or perhaps to the nature of the local business itself.
\end{abstract}

\footnotetext{
1 This note was prepared as background material for the Working Group on financial FDI of the BIS Committee of Global Financial Systems. A Spanish version has been published in the fifth number of the Financial Stability Journal of Banco de España

${ }_{2}^{2}$ All authors are affiliated with Banco de España. Alicia García Herrero and Sonsoles Gallego work at the International Economy and International Relations Department. Cristina Luna works at the Financial Institutions Department. The usual disclaimer applies. An earlier version of this note has received useful comments from Luis Javier Rodríguez and Sonsoles Eirea from Banco de España the Banking Supervision Department, from the members of the CGFS Working Group, from Francisco Vazquez (IMF) and an anonymous referee. All remaining errors are ours.
} 


\title{
INVESTING IN THE FINANCIAL SECTOR OF EMERGING COUNTRIES: POTENTIAL RISKS AND HOW TO MANAGE THEM
}

\author{
Sonsoles Gallego, Alicia García Herrero and Cristina Luna \\ Banco de España
}

\section{INTRODUCTION}

Bank international operations have continued to grow all over the world and particularly in emerging countries. The first grew mainly through cross-border operations and more recently also through the establishment of branches and subsidiaries abroad. This has changed the business potential as well as the structure of risks faced by banks and their mitigation strategies. Furthermore, the Argentine crisis has been an important negative event for banks operating abroad. Going forward, banks will need to take a broader perspective when assessing risk so that it can be better managed.

In this note we analyse the ways in which international banks operate overseas, particularly in emerging countries, the risks they face and the ways to manage them. Our perspective is that of the investor and not of the host country.

Among the many financial operations which can take place internationally, we concentrate on the banking sector, either directly through cross-border lending, or indirectly through local operations in another country, in the form of a branch or a subsidiary. We also distinguish between foreign currency versus domestic currency operations, and normal times versus crisis periods.

Two notes of caution apply. First, the classification of risks we present is largely conceptual. It does not necessarily coincide with other usual risk classification used by regulators or supervisors ${ }^{3}$ but does not contradict it either. Second, we separate risks for the purpose of the analysis although they are obviously interconnected. This means that the risks we analyse cannot simply be added and that it will be difficult to assess which type of international bank operation (cross-border, local activity through a subsidiary or through a branch) bears more risk.

\section{Recent trends}

\section{From cross-border lending to local activity:}

The operation of international banks in emerging countries has increased significantly over the last few decades but its nature has changed, and so have the risks international banks

\footnotetext{
${ }^{3}$ See, for example, Bank for International Settlements (2001) and Staking (2000)
} 
face. Back in the early 1980's, most banking business in emerging markets was conducted through cross-border lending. Since mid -1990's however, banks increased FDI to emerging markets and, as a consequence, banking business through international banks' branches and subsidiaries in emerging markets more than quadrupled.

These trends in international banking can be traced using the Bank for International Settlements consolidated banking statistics and information from national bank supervisory authorities. In the latter case, we acknowledge potential problems of comparability.

The operations of international banks in emerging countries, measured by their foreign claims ${ }^{4}$ from Bank for International Settlements statistics (which include cross-border claims and local claims in domestic and foreign currencies) amount to just about one eighth of foreign claims among developed countries (1,4 trillion US\$ in 2002 as compared to 11,4 trillion US\$ for industrial countries ${ }^{5}$ ). However, in the course of the last two decades, and particularly in the 1990s, foreign claims to emerging countries have more than doubled.

More interesting to our purposes is the fact that, in the last decade, local claims in local currency in emerging countries have escalated rapidly, reaching the current mark of $40 \%$ of all foreign claims to emerging countries. Back in the early eighties, local claims in local currency accounted for a meagre $5 \%$ of total lending to emerging countries (see Graph 1). Therefore, even if international claims to emerging countries (which include cross-border claims in all currencies and local claims in foreign currencies) are still comparatively higher today, at $60 \%$ of foreign claims, their weight in the total foreign claims of international banks in emerging countries is in a clear downward trend. In contrast, local claims in local currency in industrial countries have remained stable in the last years, at about $30 \%$ of all foreign claims (see Graph 2).

"Going local" appears to be the leading strategy of international banks which want to operate in emerging countries ${ }^{6}$. Local claims in local currency have risen sharply in Asia, Emerging Europe, Africa and especially Latin America. In this region, local claims in local currency are currently over $50 \%$ of foreign claims from levels below $5 \%$ in the early eighties (see Graph 3, 4 and 5).

In addition, it should be noted that the Bank for International Settlements consolidated data inevitably bias downwards local banking activity, since foreign-currency denominated local claims are treated as if they were cross-border lending (i.e., they are included in banks' international claims). This is particularly relevant for highly dollarized emerging countries, many of which are in the Latin American region.

This, coupled with the relatively small size of the banking systems in Latin America and Central and Eastern Europe, explains that foreign-owned banks represent over half of the banking system in many of these countries, particularly in Central and Eastern Europe ${ }^{7}$.

\footnotetext{
${ }^{4}$ Following the notation of the consolidated banking statistics of the BIS

${ }^{5}$ Operations in off-shore centres are excluded.

${ }^{6}$ See also Palmer (2000) and Clarke et al. (2001).

${ }^{7}$ See García Herrero et al. (2002)
} 


\section{The choice of branches versus subsidiaries ${ }^{8}$}

In the last few years, international banks have increasingly used subsidiaries for their operations in emerging markets, although the number of branches is still higher in some regions. This trend is not as clear in industrial countries, where the number of branches is generally larger than that of subsidiaries, particularly in financial centers ${ }^{9}$. In the case of Latin America, according to a survey on foreign bank participation by Centro de Estudios Monetarios Latinoamericanos ${ }^{10}$, there were as many as 105 foreign banks set up through Greenfield investments in 1994 while only 6 foreign banks had entered the market by acquiring a previously existing bank. ${ }^{11}$ In 1998 , foreign banks set up through Greenfield investment had increased moderately, to 136, while foreign banks entering through acquisitions (subsidiaries) rose exponentially, to 56. Even making the strong assumption that all Greenfield investment was in the form of branches, the increase in the number of subsidiaries is undoubtedly large (see Graph 6). In the case of Central and Eastern Europe, where foreign participation in the local banking system is the highest of all regions, subsidiaries are much more widespread.

The choice of the legal form is not a point of detail but may have substantial implications (Tchoegl 2003). Foreign subsidiaries are individual legal entities or incorporated banks created under the law of the host country. They have separate accounts from those of the parent company and are financially independent. They have to comply with the host country capital requirements, the host country deposit insurance scheme, and are subject to the host country supervision. In turn, foreign branches are unincorporated banks or bank offices located in a foreign country. They are an integral part of the bank and not legal entities, generally do not have separate accounts, and can not take strategic economic decisions, or incur in liabilities, or own assets in their own right.

In addition, branches are able to lend, borrow or trade on the basis of their head office's full capital base. That is why international banks usually choose this form of legal presence for wholesale and corporate banking activities. The branch can also borrow at advantageous rates as it carries the same credit rating as the head office. Subsidiaries, generally more focused on retail banking, may borrow on the basis of their own capitalization and financing, and not those of the parent bank although the latter may decide to inject funds to the subsidiary if deemed appropriate The term "financial independence" refers to this option. Such financial independence is an important tool of risk control for the parent bank during crisis periods, which is not available in the case of a branch. Branches are supposed to have full head office backing.

\section{Risks and risk mitigation in normal times.}

The evolving nature of international banks' operations in emerging markets has changed the nature of the risks faced and also the capacity to mitigate them.

\footnotetext{
8 In this section we have used different sources, among them, national banking supervisors. We acknowledge potential comparability problems.

${ }_{9}$ EU banks hold more branches than subsidiaries in the UK and Japan. However, the number of branches and subsidiaries they hold in the US is relatively equal.

${ }_{10}$ Centro de Estudios Monetarios Latinoamericanos (2002)

${ }^{11}$ While the latter were necessarily subsidiaries, the survey does not offer information whether newly set-up banks were always in the form of branches.
} 
In normal times, operating locally has some advantages which explain its expansion during the last decade. One of the most relevant is its higher business potential as the funding to increase the bank's balance sheet, after the initial investment is made, can be obtained locally. This is not the case of cross-border lending, which needs to be funded fully by the head office and whose profitability is based on the interest rate margin of that single operation. Opening a bank will always be a more leveraged operation than cross-border lending, and in consequence with more business potential.

The risks faced by an international bank with cross border lending are different in nature from those of local operations. Within the local activity, the risks are not the same for branches and subsidiaries. However, it is hard to tell which option is riskier. It will very much depend on whether the situation in the host country is normal or is a crisis one. Branches are closer to a cross-border loan in the nature of the risks they face, simply because their operations are not independent from those of the head office. In contrast, subsidiaries can be seen as closer to a local bank, as they have to be financially independent, comply with the host country capital requirements, the host country deposit insurance scheme, and are subject to the host country supervision. This is why in normal times, country risk is limited for subsidiaries to the investment made and does not affect the international bank's whole balance sheet. Cross-border transactions, however, are subject to country risk, since they are directly financed by the parent bank ${ }^{12}$ (see Box I for definitions of the different types of risks involved in banks' international operations). Apart from the general mitigation tools for insolvency risk described below, country risk can be mitigated, although not eliminated, through political risk insurance made available by official, multilateral and private sector sources ${ }^{13}$. This latter possibility is still relatively limited and underdeveloped, particularly for the local operations.

Insolvency risk affects cross-border lending and local operations of branches and subsidiaries in a similar way, since it depends on the capability and willingness to pay of all banks' borrowers. Insolvency risk interacts very closely with sovereign risk as an increase in the latter generally raises insolvency risk. An example of this is the generally automatic transmission of a downgrade in a sovereign rating to the companies of that country. Provisioning, eligible collateral, guarantees and credit derivatives are typically used to mitigate insolvency risk. However, given the scarcity of such instruments in emerging markets, other more simple mitigating techniques are also used, such as limiting the exposure to the public sector to the average levels of the local banking system or, more generally, applying strict concentration limits. ${ }^{14}$

Market risks affect both cross border and local operations of international banks. Crossborder lending bears interest rate risk, but not exchange rate risk since it is generally denominated in hard foreign currency ${ }^{15}$. Branches and subsidiaries bear interest rate and exchange rate risk in their net open positions. From the point of view of the head office or the parent bank, exchange rate risk is particularly important in branches and subsidiaries located in emerging countries where domestic currencies tend to depreciate over time.

\footnotetext{
${ }^{12}$ The same treatment is generally applied by regulators to foreign-currency local claims held in branches.

${ }^{13}$ It should be noted that the provider of insurance for sovereign risk needs to be a non resident against which the bank wants to insure itself. This is not necessary when covering insolvency risk.

${ }_{15}^{14}$ Bank for International Settlements (1998)

${ }^{15}$ However, the exchange rate risk may not fully disappear if the foreign currency in which the loan is denominated is not the domestic currency of the lender (which is the case for European banks or Japanese banks cross border lending in most emerging countries)
} 
Such exchange rate risk may stem from short open positions in foreign currency but also from the fact that the structural position or FDI is denominated in local currency but is financed in hard currency. Therefore, the valuation of the stake is made in the local currency in the subsidiary's financial statements, and is then translated into the home currency for valuation on the consolidated balance sheet. A depreciation of the local currency implies a loss. This specific type of exchange rate risk is sometimes known as "translation risk". It is larger for subsidiaries than for branches because the investment made locally is also bigger.

Market risks can be covered using derivatives (options, forwards, NDFs, futures or swaps) which are available in international markets to hedge cross-border exposures ${ }^{16}$. However, local derivatives markets are typically insufficiently developed in emerging countries to hedge very large orders without having a substantial influence on market prices. In the absence of a currency derivatives market in the country where the investment has been made, banks could also decide to use the currency of another closely correlated country. This is known as proxy-hedging, a phenomenon well known in Asia or Latin America, where investors hedge their positions in the most liquid currency markets in the regions. However proxy-hedging offers little protection against country-specific shocks. When derivatives markets are insufficiently developed, an investor may still use the cash market to hedge exchange rate risk. One example is borrowing in local currency for an amount equal to the investment, using this investment as collateral or issuing securities in the local capital market to fund the investment and match assets and liabilities. However, the size of the investment will be key to determine to what extent it can be hedged. Finally, one possibility to hedge the foreign exchange risk of the FDI would be to denominate it in a hard foreign currency. However, this is not always allowed by the host country regulations.

Liability liquidity risk should not be a problem for foreign banks in normal times, as, unlike local banks, they have the possibility to access the parent or head office. Liquidity risk can also be mitigated by general tools, such as estimating the stability of deposits, or interbank market access, as well as the interaction with the asset side of the balance sheet.

Reputational risk is likely to be higher for branches and subsidiaries with a strong regional brand name than for the more distant and usually more geographically diversified cross-border business, and might be even more important in normal times, when banks need to take full responsibility for their performance and cannot attribute responsibility to governments for their actions.

Finally, operational risk will generally tend higher when operating abroad because consolidated process, systems and the people's knowledge of the strategy of the bank is more complicated. This is more so in emerging countries where the infrastructure for banks' operation tends to be poor (payment and settlement systems among others) but it is generally lower for foreign than local banks because their operational risk managements techniques are generally common to the rest of the group.

\section{Risks in Crisis periods}

Risk mitigation is not crisis-proof since not every risk can be fully hedged and anticipated. One feature of crises is that risks that used to be manageable in normal times spill over

\footnotetext{
${ }^{16}$ See Abrams and Beato (1998)
} 
into other types of risks, making most hedges ineffective and general provisioning insufficient. Besides, unforeseen risks can appear which may be difficult to anticipate.

One archetypical case of financial crisis may arise from a sovereign default. Traditionally sovereign defaults used to hit international banks' cross-border activity or their portfolio holdings of emerging countries' external debt. This was because their local business was small but also because sovereigns typically defaulted on their external debt while maintaining a flow of payments -or compensations - to the domestic banking system. One of the most frequently used types of compensation, albeit indirect, was a surge in inflation. Against the framework of increasing foreign participation in the financial systems of emerging countries, sovereign defaults on domestic debt (or similar measures of realization of country risk) are becoming more frequent. As the Argentine case shows, their impact on the local operations of international banks can be very negative. This is more so in countries where the government is a large issuer, particular in foreign-currency, and banks hold a substantial share of government securities in their portfolios. This sharp increase in sovereign risk in a crisis situation is a clear issue but difficult to mitigate since well developed markets do not exist. Political risk insurance provided by official but also private institutions is growing but it is still insufficient for the needs. In addition, there are still problems with the definition of the terms of the realization of risk, which inhibit a faster growth. As a consequence, it is an open question whether the local activity of international banks is less exposed or better able to manage country risk than the cross-border business during difficult periods. In fact, the whole balance sheet of subsidiaries or branches is subject to country risk during a crisis.

Default by the sovereign is not the only extreme risk that banks can face in a crisis when operating locally. A political crisis leading to expropriation or nationalization of the bank could make an international bank lose the capital maintained locally and any future positive cash flow. Again, this kind of risk is extremely difficult to cover.

If country risk materialized to the extent of depleting the capital of a foreign-owned bank, a branch is in principle more exposed than a subsidiary to future losses because of the head office legal obligation to inject funds, unless ring fencing ${ }^{17}$ provisions apply. In the case of a subsidiary, being financially independent, the parent bank has the choice to inject new funds or not. Such decision will depend on a number of factors. The most important, probably is the expectation of future earnings, which will be subject to high uncertainty at the time of the decision. Other two relevant factors are the additional injection of funds needed to maintain the bank afloat, again highly uncertain, and the estimated reputational cost of exiting the country. As previously mentioned this cost may be different depending on the origin of the bank problems. The Argentine crisis seems to indicate that the reputational cost is lower if bank problems stem from the discretional action of the host country authorities.

Crisis situations can also induce "unequal treatment" between local and foreign-owned banks. When public funds are insufficient to cover all banks' needs, crisis situations may imply different access to the central bank liquidity or to government measures to support

\footnotetext{
17 Ring fencing under the US regulations refers to exceptions from repayment for potential liabilities on foreign accounts. These exceptions allow a member bank not to repay any deposit made at a foreign branch of the bank if the branch cannot repay the deposit due to 1) an act of war, insurrection or civil strife; 2) an action by the foreign government in the country in which the branch is located, unless the member bank has expressly agreed in writing to repay the deposit in those circumstances
} 
the soundness of the banking system, such as recapitalization funds after government action during a crisis contributes to wiping out banks' capital.

Banks will also have difficulties in mitigating foreign exchange risk in a crisis situation. This is particularly worrisome in highly dollarized emerging countries since foreigncurrency denominated loans will be much harder to repay by the borrowers in the event of devaluation, particularly for the non tradable sector of the economy. In addition, sovereign risks increases sharply when a large part of the public debt is denominated in hard currency. This is sometimes known as "collective credit risk", reflecting the close interaction between the foreign exchange and credit risk in times of crisis.

Another important risk of international banks' local activity in times of crisis is asset liquidity risk. In emerging countries, government paper and other generally tradable assets are generally not very liquid, and much less so in the run-up to a crisis. Assets will tend to lose value sharply precisely when more needed. This risk may affect the local and cross-border activity in a similar way. Funding liquidity risk will also be important during stress times, particularly in countries with a history of systemic banking crisis and deposit runs. From the viewpoint of the international bank, such risk will tend to be lower for subsidiaries than branches since the parent bank can decide to limit the funds granted, while this is generally not possible for a head office with its branches. However, as previously mentioned, this strategy is not risk-free. In any event, funding liquidity risk is likely to be lower for foreign banks, which typically benefit from flight to quality flows, than for local banks. In addition, banks can have their own rules of thumb to limit liquidity risk, which they apply more strictly in stress situations, such as remaining very liquid, or financing lending and reserve requirements only with deposits, without resorting to interbank borrowing.

Contagion risk appears during crisis situations. It stems from the operations in one emerging country in crisis and may affect the parent bank or head office, or the local activities of the international bank in another country. Contagion risk should be lower for the cross-border lending, which is generally less concentrated regionally and has less leverage, than for branches or subsidiaries. Contagion risk is complex to handle. The obvious way to limit it -but certainly not a fast one - is to reduce excessive regional or sector concentration by closing some lines of business in the regional area or sector or by expanding other areas or sectors with a very different economic cycle ${ }^{18}$. Other a priori ways to reduce the risk of contagion is to encourage the set up of financially-independent subsidiaries although, in certain cases, ring fencing provisions have used to limit contagion risk in the case of branches too.

Reputational risk is a particularly important issue for international banks operating in countries under crisis since this is the time when there is a certain probability that they do not to honour their obligations, either voluntarily or induced by a government decision. As previously mentioned, this risk will tend to be higher the more "voluntary" the decision. Banks with a strong regional, or global, brand are also more exposed to this risk, and particularly in the case of branches. Reputational risk is also hard to mitigate especially in the case of a branch in which liquidity support from the head office is taken for granted. However, the fact that the materialization of reputational risk may be endogenous to the reasons behind it is a mitigation tool in itself.

\footnotetext{
${ }^{18}$ See Van Rijckeghem and Weder (2001)
} 
Recent crisis events have shown the importance of upgrading risk management techniques for international banks operating in emerging markets. Some banks have started to calculate their profitability on the basis of explicitly risk-weighted capital. Other have begun to refocus their activities towards those emerging markets considered as relatively less risky. There is also partial evidence that parent companies are cutting back on the volume of intra-group loans in order to encourage their subsidiaries to become completely independent, and depend only on their own funding to grow. Finally, even if the cost of hedging is considered prohibitive in many cases, banks are reportedly using more hedges, or proxy-hedges, to mitigate their exposure.

\section{Conclusions}

The review of developments in international banking in emerging countries marks a change in pattern towards more local activity in emerging markets particularly in the form of branches, versus the traditional cross-border business. Going local has probably increased the business potential of international banks, but has also changed the risk profile of banks' balance sheets in terms of country, market and liquidity risks, although it is difficult to determine whether those risks, on the whole, have increased compared to those which international banks used to incur with cross-border lending to emerging countries. As a consequence, risk management of banks' international activities has also changed.

Both in terms of risk and of risk management techniques, it is important to differentiate between quiet periods and crisis times. Starting with the former, one of the main changes that has taken place refers to the country risk and country risk management. In quiet times, the country risk faced by subsidiaries is similar to that of a local bank, given that subsidiaries conduct a very similar business (mainly retail), are financially independent, comply with the capital requirements and the deposit insurance scheme of the host country and are subject to the host country supervision. In turn, the country risk faced by a branch is, in nature, similar to that of the cross-border business, given that the branch operations are not independent from the head office and are financed from the latter.

Insolvency risk, however, affects branches, subsidiaries and the cross-border business in a very similar manner, given that it primarily depends on the borrowers' capacity and willingness to meet their obligations.

Exposure to market risk has also changed with the increasing weight of local activity. While cross border loans are usually denominated in hard currency, the local activity is generally denominated in local currency, except in highly dollarized countries, but this is also not without risks.

Liability liquidity risk should not be a problem for international banks during quiet times, given that the parent company has the option, and the head office the obligation (except in cases of ring fencing), of transferring funds to their subsidiaries or branches in case of need. Finally, reputation risk tends to be higher for those international banks with local operations under a well-known regional name than those operating in the cross-border business which is typically more geographically diversified.

In times of crises, risks increase and are sometimes transformed into different ones, making its management more complicated particularly in emerging countries where 
financial markets tend to be underdeveloped A case in point is a sovereign default of the domestic public debt, which may have a very negative impact on the local operations of international banks. Another case is a sharp depreciation of the exchange rate in highly dollarized countries, which will translate into an increase in the credit risk faced by banks. In addition, in crisis situations unforeseen risks may appear. This is the case of a potential unequal treatment of local and international banks.

As regards risk mitigation, one key consideration is that complex risk management tools such as derivatives are usually only available in international markets. That is why risk may be harder to manage in emerging markets, and much more so during crisis times.

Summing up, we can conclude that the difference between quiet periods and crisis times is important when operating locally in emerging markets. This is so not only because of potentially higher risks, but also because risks are harder to manage given the close interactions among them. 


\section{Box: Risk classification}

Risk is defined as the probability of being hit by a loss. Risk has traditionally been classified by regulators and by risk rating agencies according to the cause originating the loss. There are many classifications of risks and the denominations change across classifications. This is partially because the origin of a loss, and thereby the risks, can be multifaceted. Acknowledging that risks should be considered globally, we provide with a working classification, useful for the purpose of our analysis.

Credit risk is the probability that a debtor defaults on its debt. This is the most relevant risk for banks, as is intrinsic to any credit transaction. When operating abroad, credit risk can take two forms: country risk and insolvency risk.

Country risk refers to host government actions (or non-actions) and necessarily implies two different territorial jurisdictions. Country risk is usually split into (i) Sovereign risk, stemming from the inability or unwillingness of a government to pay its debt. (ii) Transfer risk, which refers to the imposition of restrictions to convert local currency into hard currency and/or repatriate it, and (iii) Political risk, stemming from regulatory or government actions such as legal changes, particularly confiscation, expropriation and nationalization, as well as war or civil unrest.

Insolvency risk is the probability of loss because a debtor defaults in its obligations due to the normal course of business. Insolvency risk can stem from all sectors in the economy. It increases during economic downturns or if country risk rises sharply. This implies that credit events such as a sovereign default, moratorium, currency inconvertibility, expropriations or war are generally accompanied by a parallel increase in insolvency risk.

Market risk stems from fluctuations in interest, exchange rates, and asset prices. It is particularly important for some types of international bank business, such as securities trading or in general investment banks.

Liquidity risk can be regarded from the asset or liability side of a bank's balance sheet. Asset liquidity risk reflects the possibility that an entity will be unable to unwind a position in a financial instrument because the market is not deep enough or there is a disruption in its functioning when the bank wishes to liquidate that position. Liability liquidity risk or funding risk stems from the maturity of deposits, many of which can be withdrawn at any time.

Contagion risk is the possibility that problems in a subsidiary or branch may directly affect the head office or parent bank or another branch or subsidiary of the same international bank in a country related to the one where the problem initiates. The latter is sometimes called "common lender contagion channel"19 and is higher the more the investment is concentrated in a single region or sector.

Reputational risk is related to a potential worsening of the corporate image of a bank if it fails to honour its commitments or obligations. The reputation of a bank depends on the corporate image that a foreign bank has accumulated in a country or region or even globally.

Finally, operational risk is defined as the possibility to incur in losses because of inadequate or failed internal processes, people and systems or from external events.

\footnotetext{
${ }^{19}$ Van Rijckeghem and Weder (2001)
} 


\section{Graphic 1}

Structure of Foreign Claims in Emerging Countries

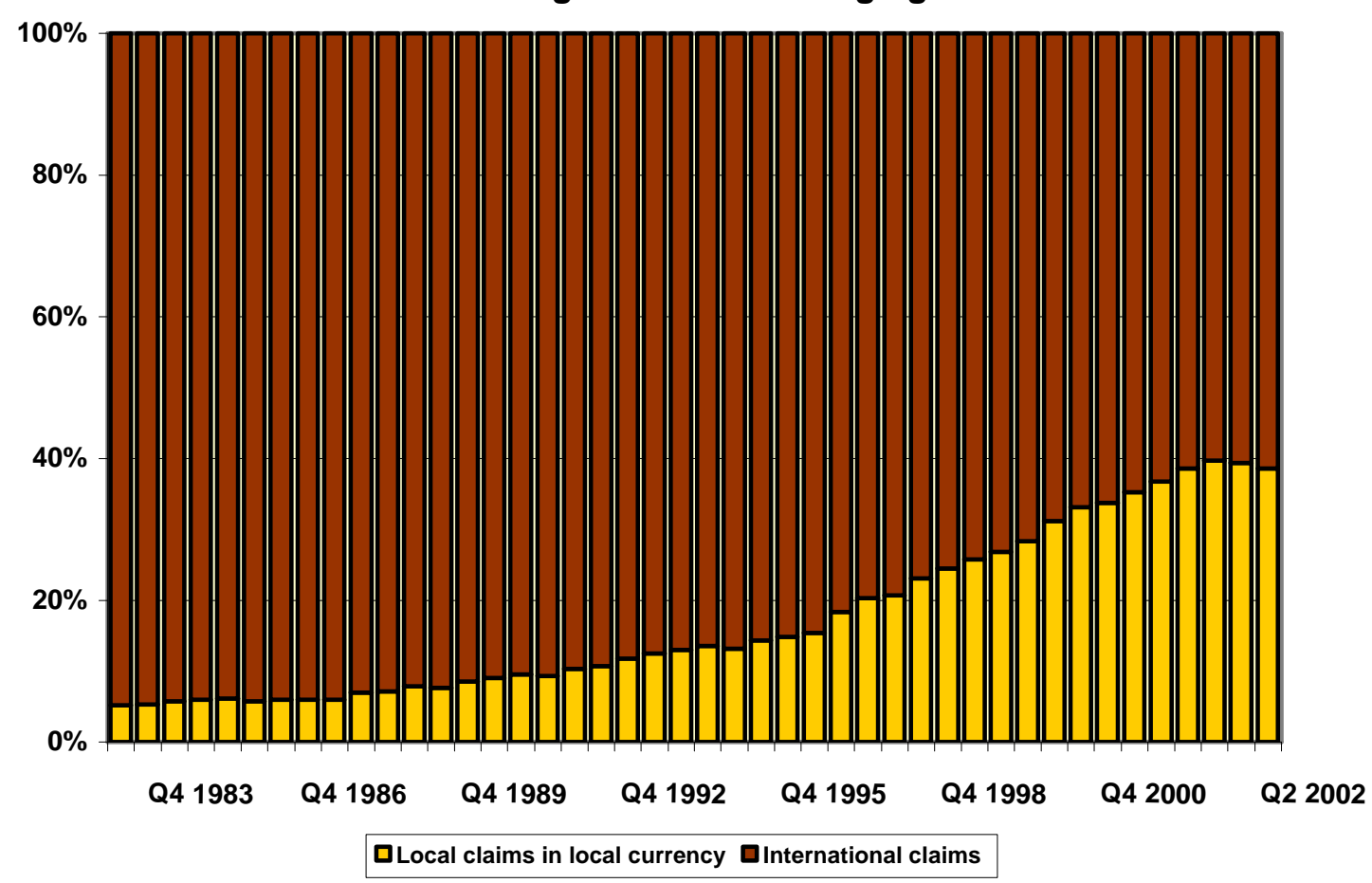

Graphic 2

Structure of Foreign Claims in Industrial Countries

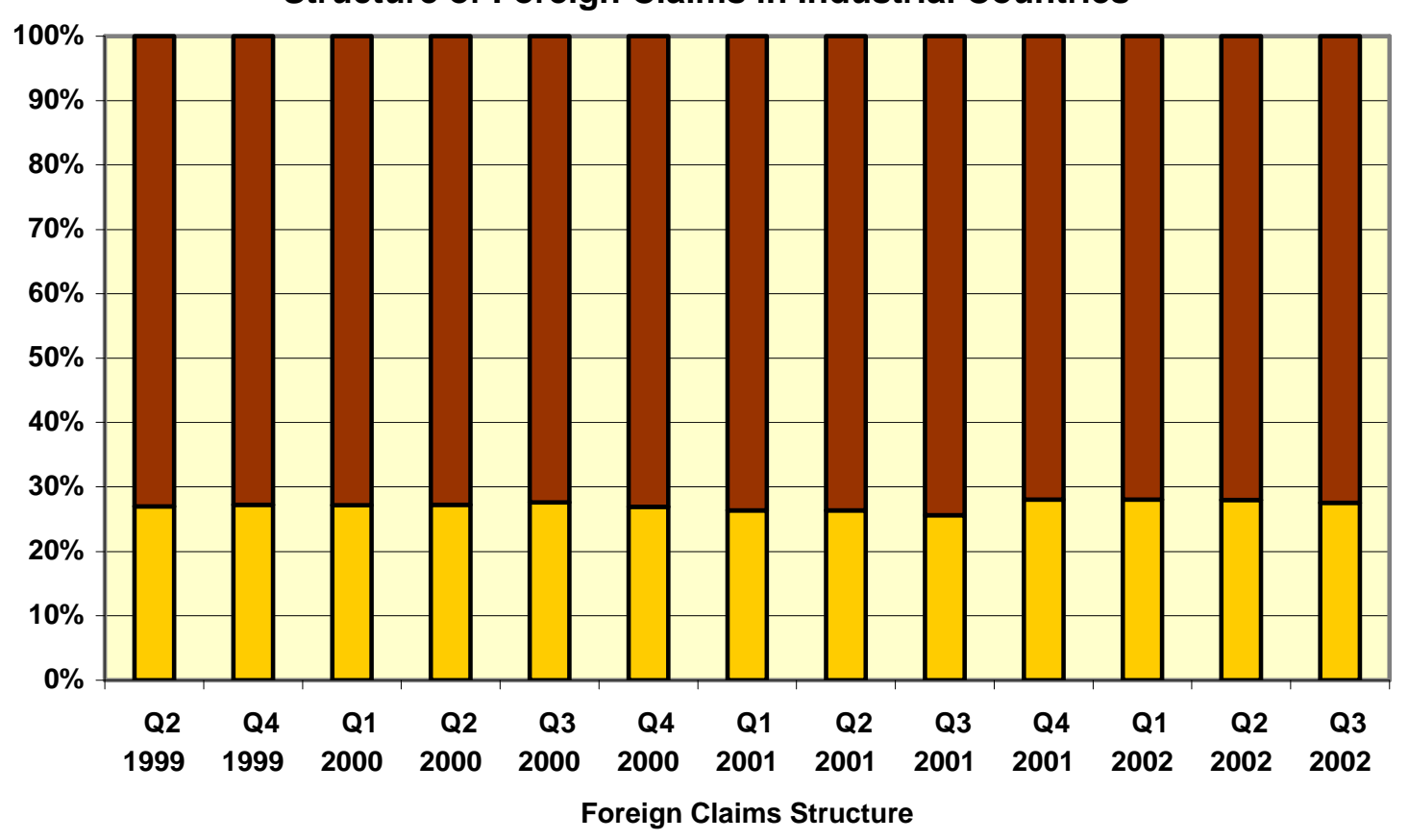

口Local claims in local currency

DInternational Claims 


\section{Graphic 3}

Structure of Foreign Claims in Latinoamerica

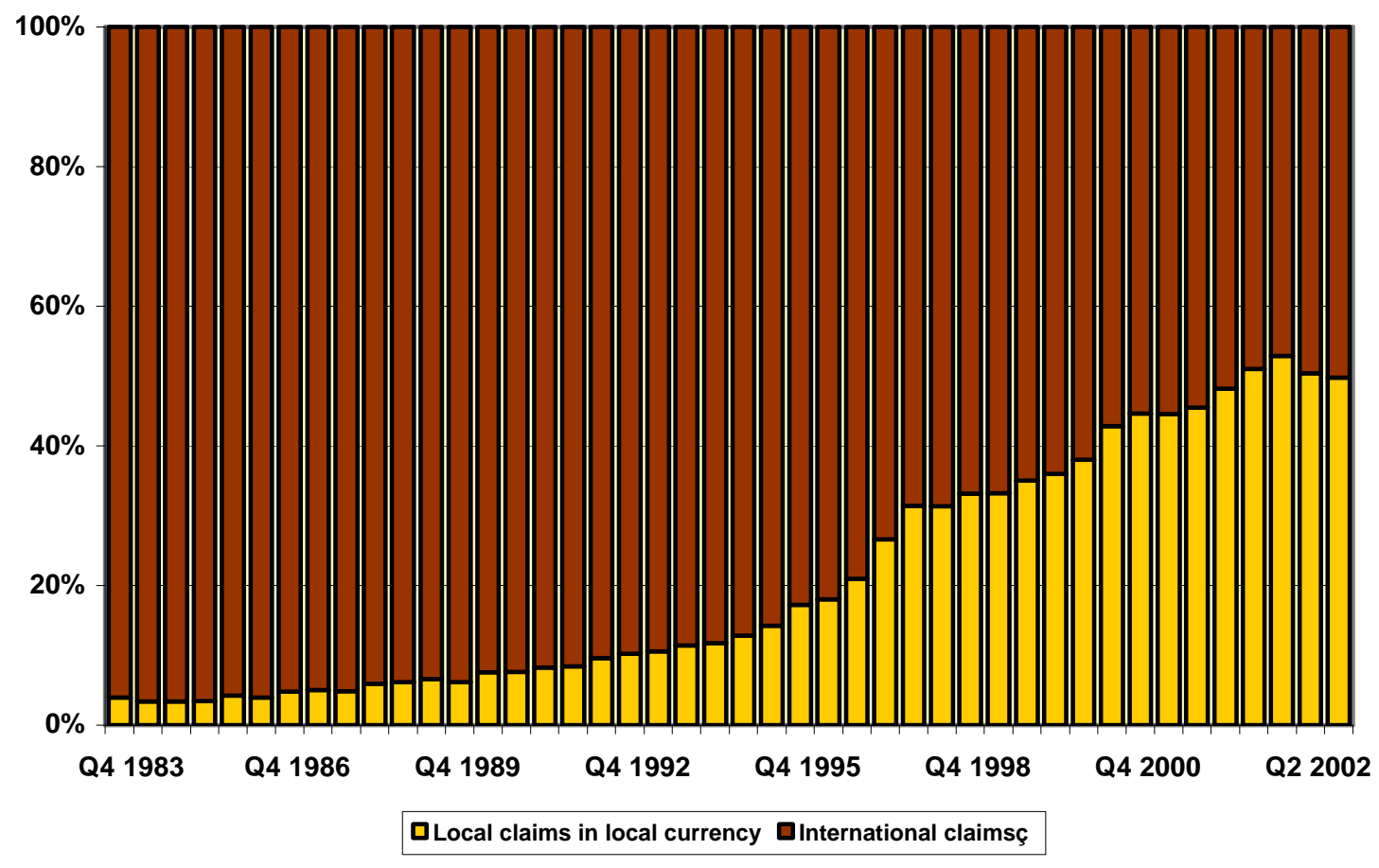

Graphic 4

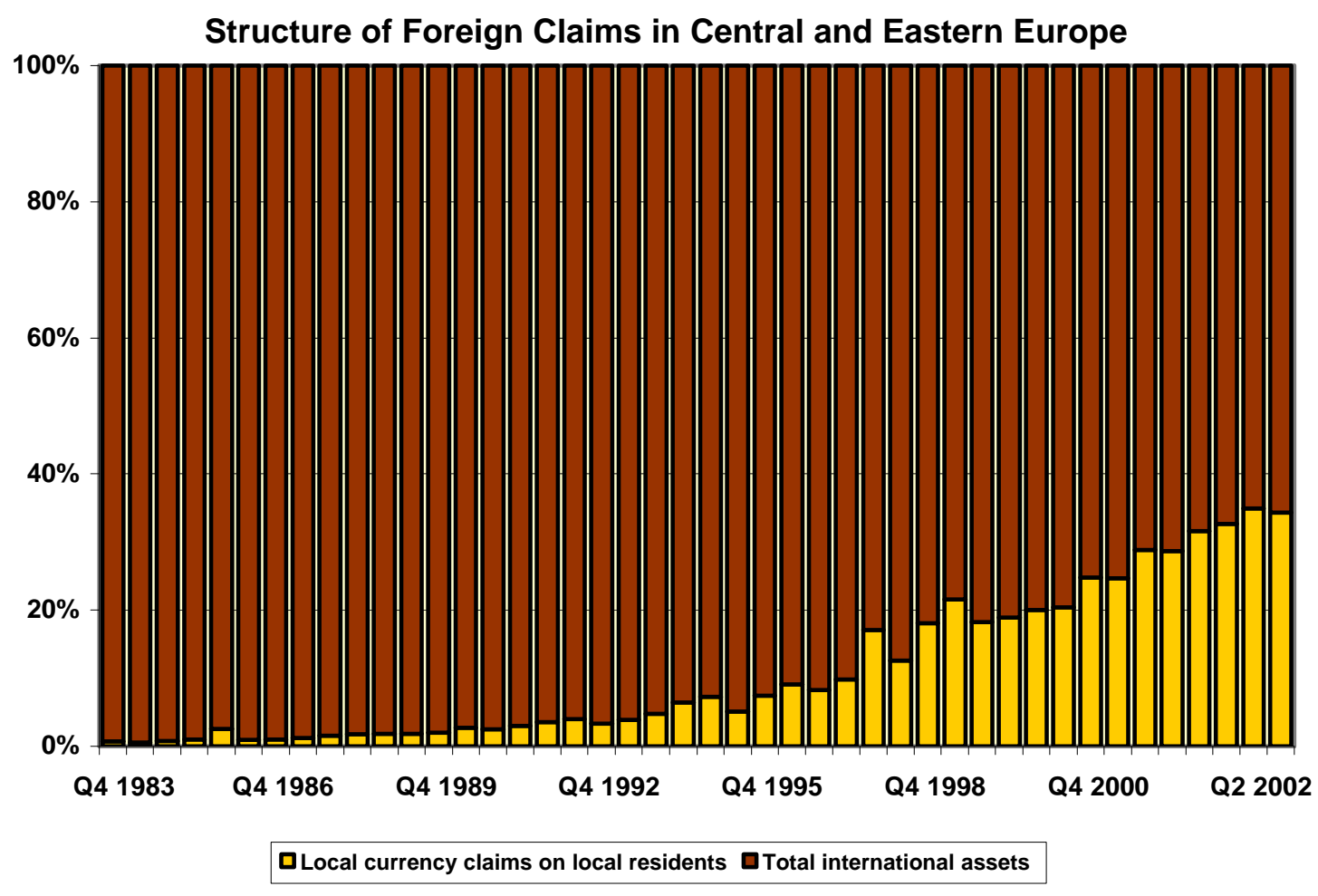




\section{Graphic 5}

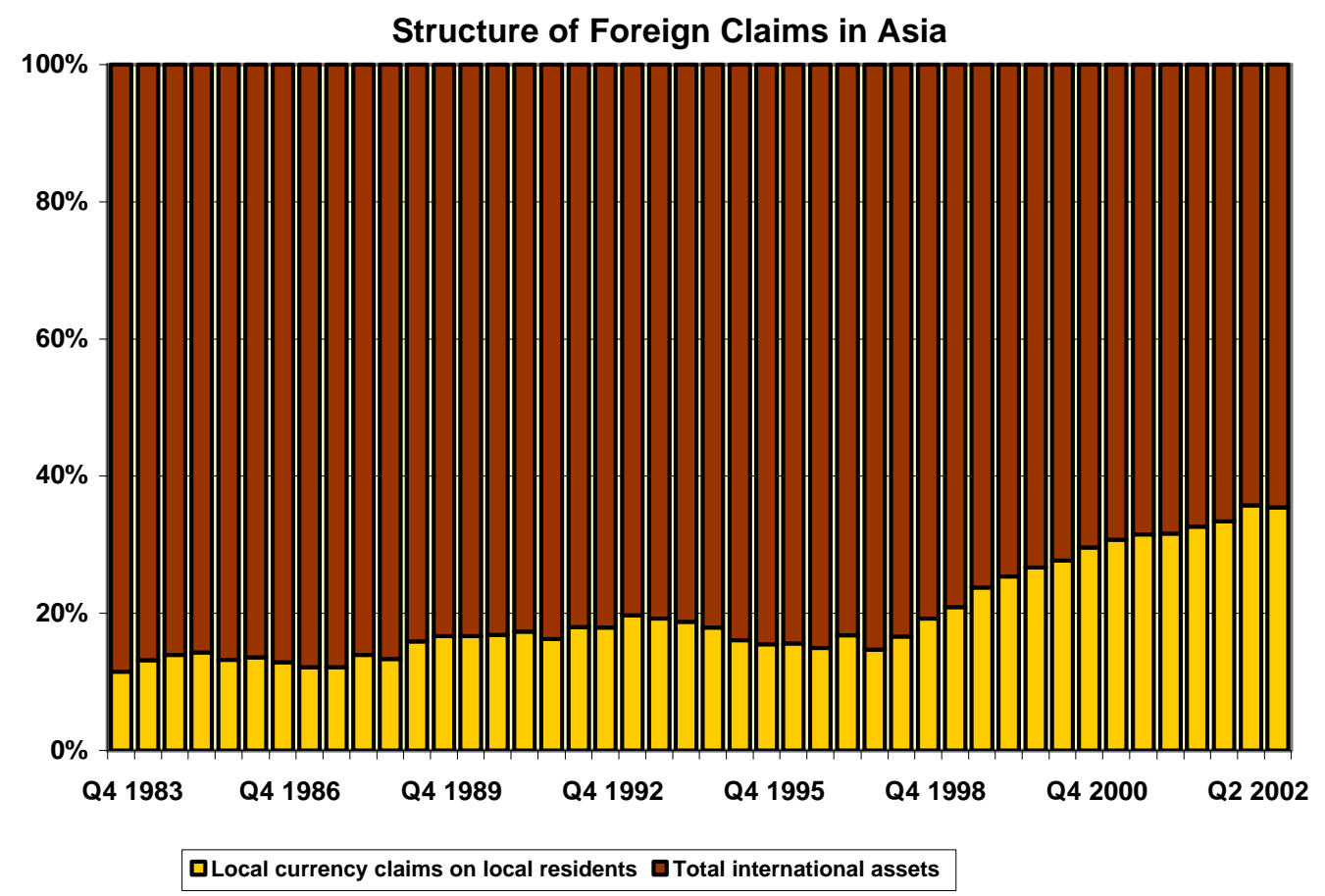

Graphic 6

Number of foreign-owned banks in Latin America and entry mode

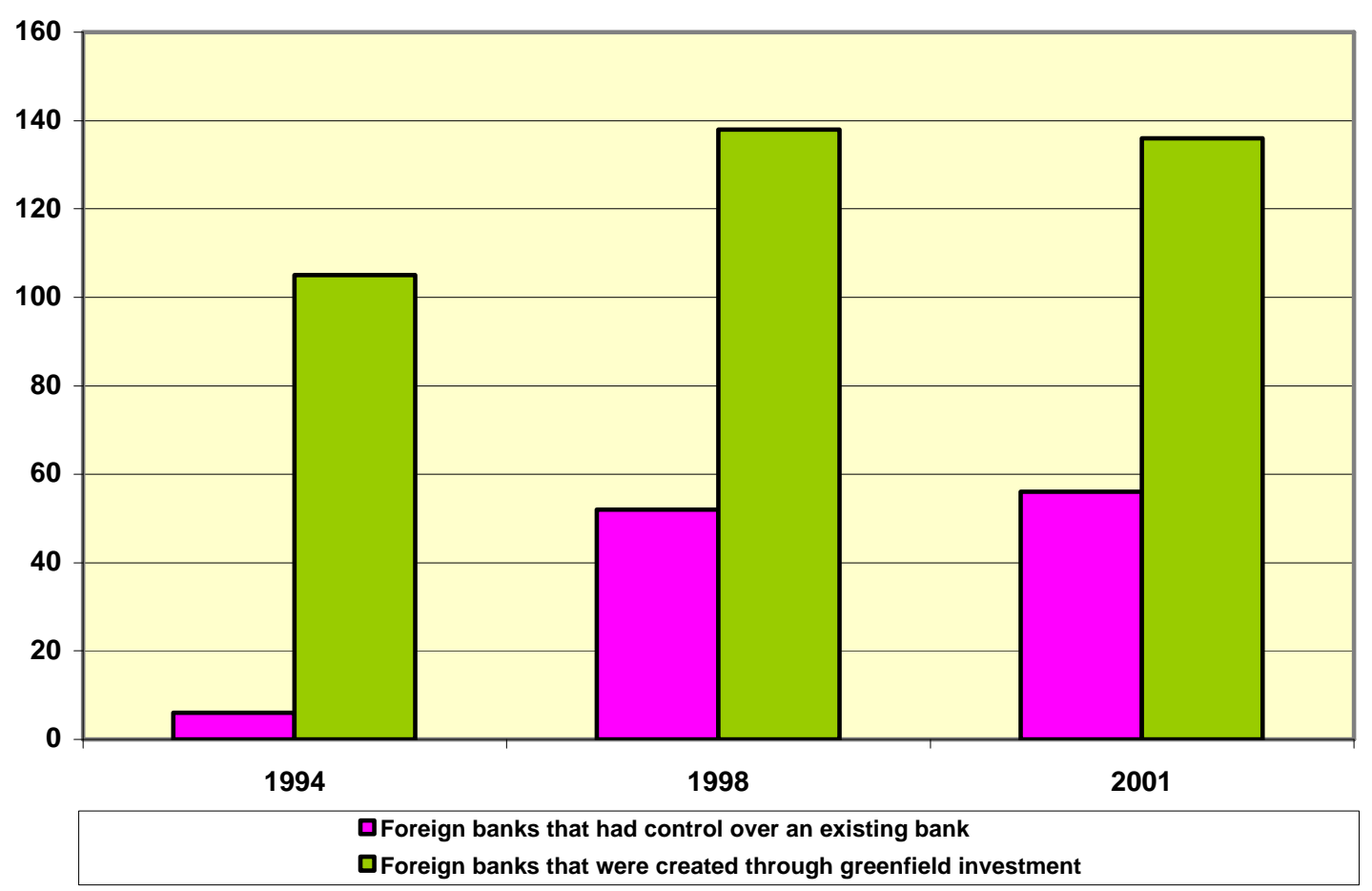




\section{REFERENCES}

Abrams, K., and P. Beato (1998), "The Prudential Regulation and Management of Foreign Exchange Risk", IMF Working Paper WP/98/37, International Monetary Fund.

Bank for International Settlements (1998), "On the Use of Information and Risk Management by International Banks, The Federal Reserve System, Surveys and Reports.

Bank for International Settlements (2001), "Risk Management Practices and Regulatory Capital. Cross-Sectoral Comparison", The Joint Forum, Basel Committeee on Banking Supervision, BIS Joint Publications. Also available in IOSCO website.

Centro de Estudios Monetarios Latinoamericanos (2002), "Análisis de los efectos del incremento de la actividad de la banca extrajera en América Latina y el Caribe", in Monetaria, Vol. 25, No. 3.

Clarke, G., Cull, R., Martinez Peria, S. and S. M. Sánchez (2001), "Foreign Bank Entry: Experience, Implications for Developing Countries, and Agenda for Further Research", The World Bank Working Papers, Domestic Finance. Saving, Financial Systems, Stock Markets Series, No. 2698, The World Bank.

García Herrero, A., Santillán, J., Gallego, S., Cuadro, L. and C. Egea (2002), "Latin American Financial Development in Perspective", Documento de Trabajo del Servicio de Estudios, No. 0216, Banco de España.

Palmer, D. E. (2000), "U.S. Bank Exposure to Emerging-Market Countries during Recent Financial Crises", Federal Reserve Bulletin, The Federal Reserve System.

Staking, K. B. (2000), "Political Risks: Is insurance needed?", IFM Bulletin, (http://www.iadb.org/sds/IFM/publication/gen 1541035 e.htm).

Tschoegle A. (2003) "Financial Crises and the Presence of Foreign Banks". Wharton Schoold of the University of Pennsylvania.

Van Rijckeghem, C. and B. Weder (2001), "Sources of Contagion: Is It Finance or Trade?", Journal of International Economics, Vol. 54, pp. 293-308. 